[Chem. Pharm. Bull.

35(11)4473-4481(1987)]

\title{
Thioalkoxytributyl- and Thioalkoxytriphenylphosphonium Salts: Preparation and Application to the Synthesis of Thiolesters and Unsymmetrical Sulfides
}

\author{
Hidenobu Ohmori, * Hatsuo Maeda, Kohichi Konomoto, \\ KiYoshi SaKaI, and Masaichiro Masui \\ Faculty of Pharmaceutical Sciences, Osaka University, \\ 1-6 Yamadaoka, Suita, Osaka 565, Japan
}

(Received May 19, 1987)

\begin{abstract}
Thioalkoxyphosphonium salts, $\mathrm{Ph}_{3} \mathrm{P}^{+} \mathrm{SR} \mathrm{ClO}_{4}^{-}(3)$ and $\mathrm{Bu}_{3} \mathrm{P}^{+} \mathrm{SR} \mathrm{X}^{-}\left(\mathrm{X}=\mathrm{ClO}_{4}\right.$ and $\left.\mathrm{BF}_{4}\right)(5)$, have been prepared from the corresponding tertiary phosphines and disulfides by simple procedures, which involve (i) constant current electrolysis in acetonitrile in the presence of either $\mathrm{HClO}_{4}$ (for 3) or $\mathrm{PhCOOH}$ and $\mathrm{LiX}$ (for 5), and (ii) stirring an equimolar mixture of a phosphine, a disulfide, $\mathrm{PhCOOH}$, and $\mathrm{LiX}$ in acetonitrile at ambient temperature. For the preparation of $\mathbf{3}$, which have been reported as useful reagents for the synthesis of unsymmetrical disulfides, the electrochemical method is recommended, while for $\mathbf{5}$ the latter non-electrochemical procedure gave better results. Reactions of the phosphonium salts $\mathbf{5}$ with carboxylic acids and primary alcohols in benzene at ambient temperature gave thiolesters and unsymmetrical sulfides, respectively, in fair to excellent yields.
\end{abstract}

Keywords - triphenylphosphine; tributylphosphine; disulfide; thioalkoxyphosphonium salt; thiolester; unsymmetrical sulfide

Previously we reported that thioalkoxytriphenylphosphonium perchlorates $\left[\mathrm{Ph}_{3} \mathrm{P}^{+} \mathrm{SR}\right.$ $\left.\mathrm{ClO}_{4}^{-}\right]$(3), prepared electrochemically from $\mathrm{Ph}_{3} \mathrm{P}(1)$ and RSSR (2), are useful reagents for the synthesis of unsymmetrical disulfides. ${ }^{1)}$ Although a phosphonium ion of type $\left[\mathrm{Ph}_{3} \mathrm{P}^{+} \mathrm{SPh}\right.$ $\mathrm{PhS}^{-}$] has been suggested as the primary intermediate in the preparation of thiolesters from $\mathbf{1}$, $2(\mathrm{R}=\mathrm{Ph})$, and carboxylic acids, ${ }^{2)}$ attempts to prepare thiolesters from $3(\mathrm{R}=$ alkyl) and carboxylic acids were unsuccessful: with $3(\mathrm{R}=\mathrm{Ph})$, thiolester formation was actually effected. ${ }^{3)}$ On the other hand, thiomethoxytributylphosphonium salts $\left[\mathrm{Bu}_{3} \mathrm{P}^{+} \mathrm{SMe} \mathrm{X}^{-}\right.$ $\left(\mathrm{X}=\mathrm{BF}_{4}, \mathrm{OSO}_{2} \mathrm{CF}_{3}\right.$, and $\left.\mathrm{OSO}_{2} \mathrm{C}_{6} \mathrm{H}_{4} \mathrm{Me}-p\right)$ ] have recently been shown to react with carboxylic acids and primary alcohols to give the corresponding thiolesters and unsymmetrical sulfides, respectively. ${ }^{4)}$ However, thioalkoxyphosphonium salts are usually obtained by the reaction of phosphine sulfides with alkylating agents such as $\mathrm{R}_{3} \mathrm{OBF}_{4}, \mathrm{ROSO}_{2} \mathrm{CF}_{3}$, and $\mathrm{ROSO}_{2} \mathrm{C}_{6} \mathrm{H}_{4} \mathrm{Me}-p$; and, as far as we are aware, most of the phosphonium salts synthesized by this method are limited to the methylthio and ethylthio derivatives. ${ }^{4,5)}$ Since the electrochemical oxidation of $\mathbf{1}$ in the presence of $\mathbf{2}$ has been suggested to afford $\mathbf{3}$ with various alkyl groups, ${ }^{6)}$ thioalkoxytributylphosphonium salts $\left[\mathrm{Bu}_{3} \mathrm{P}^{+} \mathrm{SR} \mathrm{X} \mathrm{X}^{-}\right](5)$ were also expected to be prepared electrochemically from $\mathrm{Bu}_{3} \mathrm{P}(4)$ and 2 . This paper reports the preparation of $5(\mathrm{X}=$ $\mathrm{ClO}_{4}$ and $\mathrm{BF}_{4}$ ) along with a modification of the electrochemical method for 3 . Further, the reactions of 5 with carboxylic acids and alcohols were examined. Unexpectedly, the phosphonium salts $\mathbf{3}$ and $\mathbf{5}$ were also obtained without electrolysis from the disulfides $\mathbf{2}$ and the phosphines 1 and 4, respectively. 


\section{Results and Discussion}

\section{Improved Electrochemical Preparation of the Phosphonium Salts 3}

Our earlier method for $\mathbf{3}$ involved rather troublesome controlled potential electrolysis (CPE) in a divided electrolysis cell. ${ }^{6}$ ) Constant current electrolysis (CCE) in an undivided cell, if possible, will be more practical for synthetic purposes. ${ }^{7)}$

$\mathrm{CCE}$ of a mixture of the phosphine $\mathbf{1}$, a disulfide 2 , and $\mathrm{HClO}_{4}{ }^{8)}$ (amount, 1:2:2) in $\mathrm{MeCN}$ was found to give 3 in yields comparable to or better than those attained ${ }^{6)}$ by the CPE. The results are summarized in Table I. In addition to the greater ease of operations, the CCE method allows the preparation of larger amounts of $\mathbf{3}$ with even improved yields [see Table I, for $3(\mathrm{R}=\mathrm{Me}$ and $\mathrm{Ph})$ ]. Perchloric acid is employed not only as the supporting electrolyte but also as a proton source, which will be reduced preferentially at the cathode to prevent the reduction of 3 once formed at the anode. ${ }^{9)}$ When the acid was replaced by $\mathrm{NaClO}_{4}$, the

TABLE I. Preparation of $\mathrm{Ph}_{3} \mathrm{P}^{+} \mathrm{SR} \mathrm{ClO}_{4}^{-}$(3) by $\mathrm{CCE}^{a)}$

\begin{tabular}{llll}
\hline \hline $\mathrm{R}$ & $\begin{array}{c}\text { Yield }(\%)^{b, c)} \\
\text { of } \mathbf{3}\end{array}$ & $\mathrm{R}$ & $\begin{array}{c}\text { Yield }(\%)^{b, c)} \\
\text { of } \mathbf{3}\end{array}$ \\
\hline $\mathrm{Me}$ & $77(88)^{d)}$ & sec $-\mathrm{Bu}$ & 53 \\
$\mathrm{Et}$ & 68 & tert $-\mathrm{Bu}$ & $e)$ \\
$\mathrm{Pr}$ & 67 & $\mathrm{Ph}$ & $63(94)^{d)}$ \\
$\mathrm{Bu}$ & 67 & $\mathrm{PhCH}_{2}$ & 48 \\
\hline
\end{tabular}

a) In $\mathrm{MeCN}(40 \mathrm{ml})$ containing $1(2 \mathrm{mmol}), 2(4 \mathrm{mmol})$, and $\mathrm{HClO}_{4}(4 \mathrm{mmol})$ unless otherwise noted. b) Isolated yield after recrystallization. c) $\mathrm{Ph}_{3} \mathrm{PO}$ was formed as the major by-product. $d$ ) In $\mathrm{MeCN}(150 \mathrm{ml})$ containing $1(50 \mathrm{mmol}), 2(100 \mathrm{mmol})$, and $\mathrm{HClO}_{4}(100 \mathrm{ml})$. e) $\mathrm{Ph}_{3} \mathrm{PS}(65 \%)$ and $\mathrm{Ph}_{3} \mathrm{PO}$ $(28 \%)$ were obtained together with MeCONH-tert-Bu (yield, not determined).

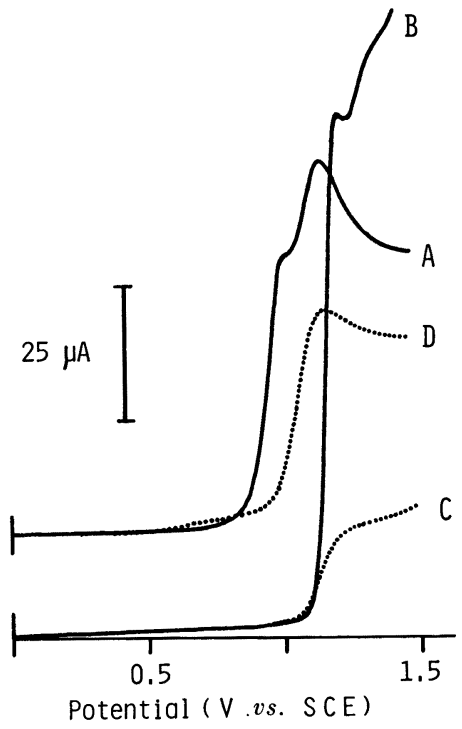

Fig. 1. Cyclic Voltammograms of $\mathbf{1}$ and 2 in $\mathrm{MeCN}\left(0.1 \mathrm{M} \mathrm{NaClO}_{4}\right)$

A, 1 (5.0 mM); B, $2(\mathrm{R}=\mathrm{Me})(4.9 \mathrm{~mm}) ; \mathrm{C}, 1(5.0$ $\mathrm{mm})+\mathrm{HClO}_{4}(10 \mathrm{~mm}) ; \mathrm{D}, \mathrm{Ph}_{3} \mathrm{PH}^{+} \mathrm{ClO}_{4}(5.0 \mathrm{~mm})$ : at $25^{\circ} \mathrm{C}$; glassy carbon anode $\left(\right.$ area $\left.=0.071 \mathrm{~cm}^{2}\right)$; voltage sweep rate, $50 \mathrm{mV} / \mathrm{s}$.

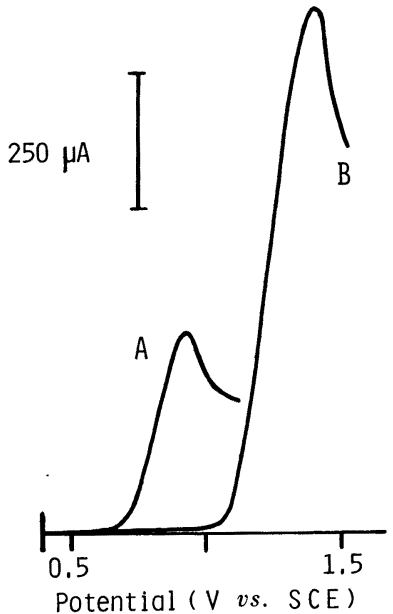

Fig. 2. Cyclic Voltammograms of 4 and 2 in $\mathrm{MeCN}$

A, $4(63 \mathrm{~mm})$ and $\mathrm{LiClO}_{4}(250 \mathrm{~mm}) ; \mathrm{B}, \mathrm{A}+[2(\mathrm{R}=$ $\mathrm{Me})(125 \mathrm{~mm})$ and $\mathrm{PhCOOH}(63 \mathrm{~mm})$ ]: at $25^{\circ} \mathrm{C}$; glassy carbon anode (area $=0.071 \mathrm{~cm}^{2}$ ); voltage sweep rate, $50 \mathrm{mV} / \mathrm{s}$. 
supporting electrolyte in the CPE method, $\left.{ }^{6}\right)$ the yield of $3(\mathrm{R}=\mathrm{Me})$ decreased to $\left.28 \%{ }^{\circ}{ }^{10}\right)$

The phosphonium salt $3(\mathrm{R}=$ tert-Bu) was not obtained by either of the methods, CPE and $\mathrm{CCE}$. In the latter electrolysis, $\mathrm{Ph}_{3} \mathrm{PS}$ was the major product and formation of MeCONH-tert-Bu was recognized [see Table I, footnote e)]. On the other hand, $\mathrm{Ph}_{3} \mathrm{PO}$ accounted for most of the by-products in the preparation of $3(\mathrm{R}=\mathrm{Me})$. These results suggest that $3(\mathrm{R}=$ tert $-\mathrm{Bu})$ is formed in the electrolysis solution but decomposes rapidly by an $S_{N} 1$ type mechanism. Reaction of the resulting tert-butyl cation with $\mathrm{MeCN}$ followed by hydrolysis will give the acetamide. ${ }^{8)}$ Electrochemical acetamidation is well known when a carbenium ion is generated in $\mathrm{MeCN} .{ }^{11)}$

Figure 1 shows the cyclic voltammograms of 1 and $2(R=M e)$ in $M e C N$. Based on the observation that $\mathbf{1}$ is oxidized at a potential less positive than $\mathbf{2}$ (see Fig. 1, curves A and B), together with coulometric results, ${ }^{12)}$ the process of formation of 3 in the CPE method has been suggested to be as described in Eq. 2 (Chart 1), where the radical cation from 1 initially formed at the electrode attacks the disulfide. In the presence of $\mathrm{HClO}_{4}$, however, the voltammetric oxidation potential of $\mathbf{1}$ and $\mathbf{2}$ are close to each other (Fig. 1, curves B and C). ${ }^{13}$ ) Thus, an alternative process involving the attack of $\mathbf{1}$ on the radical cation generated from 2 (Eqs. 1 and 3) may take place concurrently with that represented by Eqs. 1 and 2.

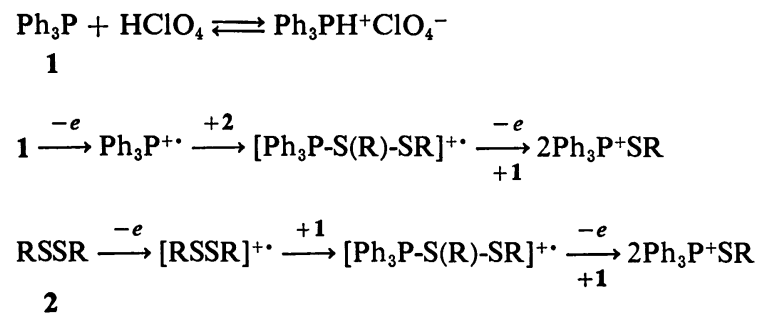

Chart 1

\section{Electrochemical Preparation of the Phosphonium Salts 5}

When a mixture of the phosphine 4 and a disulfide 2 was electrolyzed similarly with excess $\mathrm{HClO}_{4}$ as the proton source, the yield of 5 seldom exceeded $50 \%{ }^{14)}$ and in some cases 4 was recovered from the electrolysis solution as the hydroperchlorate. These results can be explained as follows. Since 4 is a stronger base $\left(\mathrm{p} K_{\mathrm{a}}=8.43\right)$ than $\left.1\left(\mathrm{p} K_{\mathrm{a}}=2.73\right),{ }^{15}\right)$ the protonation equilibrium in the presence of $\mathrm{HClO}_{4}$ must lie far to the right ( $c f$. Eq. 1), and only a small amount of $\mathbf{4}$ will be present in the unprotonated form, as evidenced by the observation that the voltammetric oxidation peak of 4 in $\mathrm{MeCN}$ (Fig. 2) disappeared completely on addition of the acid. Consequently, if the formation of $\mathbf{5}$ proceeds by a mechanism similar to that in Eq. 3, the attack of $\mathbf{4}$ on the disulfide radical cation (the 2nd step) will be slower than in the case of 3 and the possibility of side reactions of the radical cation will be enhanced. The major part of the latter reactions would be caused by water, which is added unavoidably to the medium along with $\mathrm{HClO}_{4}{ }^{8)}$

The yield of 5 increased when $\mathrm{HClO}_{4}$ was replaced by $\mathrm{LiClO}_{4}$ and $\mathrm{PhCOOH}$, though the voltammetric peak of $\mathbf{4}$ was again absent in the solution employed for the electrolysis (Fig. 2, curve B). Table II lists the best results among those obtained on $\mathrm{CCE}$ in $\mathrm{MeCN}$ under various electrolysis conditions, where the electrolysis solution was composed of 4, 2, $\mathrm{PhCOOH}$, $\mathrm{LiClO}_{4}$, and suspended alumina. When 4 was added to a solution of $\mathrm{PhCOOH}$ and $\mathrm{LiClO}_{4}$ in $\mathrm{MeCN}$, a large portion of $\mathrm{PhCOOH}$ was separated out as PhCOOLi, indicating that the electrolysis had been conducted in a nominally anhydrous solution of $\mathrm{HClO}_{4}$ in $\mathrm{MeCN}$ saturated with $\mathrm{PhCOOLi}$. PhCOOH can be replaced by other organic acids with similar acidity, but the yield of $\mathbf{5}$ was not improved. The presence of PhCOOLi (or a lithium salt of an 
TABLE II. Preparation of $\mathrm{Bu}_{3} \mathrm{P}^{+} \mathrm{SR} \mathrm{ClO}_{4}{ }^{-}(5)$ by $\mathrm{CCE}^{a}$

\begin{tabular}{|c|c|c|c|c|c|c|c|}
\hline \multicolumn{4}{|c|}{ Electrolysis } & \multicolumn{4}{|c|}{ Electrolysis } \\
\hline $\mathrm{R}$ & $\begin{array}{c}\text { Current } \\
(\mathrm{mA})\end{array}$ & $\begin{array}{l}\operatorname{Time}^{b)} \\
(\min )\end{array}$ & $\begin{array}{c}\text { Yield }(\%)^{c)} \\
\text { of } \mathbf{5}\end{array}$ & $\mathrm{R}$ & $\begin{array}{c}\text { Current } \\
(\mathrm{mA})\end{array}$ & $\begin{array}{l}\text { Time }^{b)} \\
(\min )\end{array}$ & $\begin{array}{l}\text { Yield }(\%)^{c)} \\
\text { of } 5\end{array}$ \\
\hline $\mathrm{Me}$ & 400 & 30 & 57 & $\sec -\mathrm{Bu}$ & 100 & 120 & - \\
\hline Et & 200 & 60 & 38 & tert $-\mathrm{Bu}$ & 100 & 120 & d) \\
\hline $\operatorname{Pr}$ & 100 & 120 & 29 & $\mathrm{Ph}$ & 100 & 120 & $35(50)^{e)}$ \\
\hline $\mathrm{Bu}$ & 100 & 120 & 25 & $\mathrm{PhCH}_{2}$ & 100 & 120 & 51 \\
\hline
\end{tabular}

a) In MeCN (40 ml) containing 4 ( $7.5 \mathrm{mmol}), 2(15 \mathrm{mmol})$, PhCOOH (7.5 mmol), $\mathrm{LiClO}_{4}(30 \mathrm{mmol})$, and $\mathrm{Al}_{2} \mathrm{O}_{3}(0.2 \mathrm{~g})$. b) Time required to consume $1 \mathrm{~F}$ per mole of 4 . c) Isolated yield after recrystallization. d) $\mathrm{Bu}_{3} \mathrm{PS}$ was obtained in $81 \%$ yield. $e$ ) In the presence of $\mathrm{PhSH}(12 \mathrm{mmol})$ in addition to the materials listed in $a$ ).

TABLE III. Preparation of $\mathrm{Ph}_{3} \mathrm{P}^{+} \mathrm{SR} \mathrm{ClO}_{4}{ }^{-}$(3) and $\mathrm{Bu}_{3} \mathrm{P}^{+} \mathrm{SR} \mathrm{X} \mathrm{X}^{-}$(5) by the Non-electrochemical Procedure ${ }^{a)}$

\begin{tabular}{|c|c|c|c|c|c|c|c|}
\hline \multirow{2}{*}{$\mathrm{R}$} & \multirow{2}{*}{$\begin{array}{l}\text { Yield }(\%)^{b)} \\
\text { of } 3\end{array}$} & \multicolumn{2}{|c|}{ Yield $(\%)^{b)}$ of } & \multirow{2}{*}{$\mathrm{R}$} & \multirow{2}{*}{$\begin{array}{c}\text { Yield }(\%)^{b)} \\
\text { of } \mathbf{3}\end{array}$} & \multicolumn{2}{|c|}{ Yield $(\%)^{b)}$ of } \\
\hline & & $5\left(\mathrm{X}=\mathrm{ClO}_{4}\right)$ & $5\left(\mathrm{X}=\mathrm{BF}_{4}\right)$ & & & $5\left(\mathrm{X}=\mathrm{ClO}_{4}\right)$ & $5\left(\mathrm{X}=\mathrm{BF}_{4}\right)$ \\
\hline $\mathrm{Me}$ & 78 & 69 & 72 & $s e c-\mathrm{Bu}$ & 11 & 0 & 0 \\
\hline Et & 54 & 68 & 50 & tert-Bu & 0 & 0 & 0 \\
\hline $\operatorname{Pr}$ & 50 & 64 & 39 & $\mathrm{Ph}$ & 54 & $3^{c)}$ & 0 \\
\hline $\mathrm{Bu}$ & 55 & 48 & 9 & $\mathrm{PhCH}_{2}$ & 0 & 75 & 63 \\
\hline
\end{tabular}

a) For 3, in $\mathrm{MeCN}(10 \mathrm{ml})$ containing $5 \mathrm{mmol}$ each of $1,2, \mathrm{PhCOOH}$, and $\mathrm{LiClO}_{4}$, and $\mathrm{Al}_{2} \mathrm{O}_{3}(0.2 \mathrm{~g})$. For 5 , in $\mathrm{MeCN}(20 \mathrm{ml})$ containing $12.5 \mathrm{mmol}$ each of $4,2, \mathrm{PhCOOH}$, and $\mathrm{LiX}$, and $\mathrm{Al}_{2} \mathrm{O}_{3}(0.2 \mathrm{~g})$. b) Isolated yield after recrystallization. c) $\mathrm{PhCOSPh}$ was formed as the major product (yield not determined).

organic acid) seems indispensable, though the amount dissolved in the reaction medium in equilibrium with the deposited salt must be small. Thus, $\mathbf{5}$ was not obtained on CCE of a mixture of $\mathrm{Bu}_{3} \mathrm{PH}^{+} \mathrm{ClO}_{4}^{-}, 2, \mathrm{LiClO}_{4}$, and suspended alumina in $\mathrm{MeCN}$. The role of $\mathrm{PhCOOLi}$ or $\mathrm{PhCOO}^{-}$in the medium may be to assist the deprotonation of $\mathrm{Bu}_{3} \mathrm{PH}^{+}$formed from 4 and the $\mathrm{HClO}_{4}$. Use of $\mathrm{NaClO}_{4}$ as the supporting electrolyte was less effective. Electrolysis at lower temperatures gave poor results.

\section{Preparation of 5 by Non-electrochemical Reaction}

When the electrolysis solution (see above) was simply allowed to stand as a control experiment, formation of $\mathbf{5}$ was hardly recognized within the time required for the electrolysis. After a longer period ( $c a .10 \mathrm{~h}$ ), however, $\mathbf{5}$ was produced in a yield higher than those attained in the CCE except for $5(\mathrm{R}=\mathrm{Ph})$. The following conditions were found to be preferable for the preparation of 5: stirring an equimolar mixture of 2, 4, $\mathrm{PhCOOH}$, and $\mathrm{LiClO}_{4}$ or $\mathrm{LiBF}_{4}$ in $\mathrm{MeCN}$ with suspended alumina for $12 \mathrm{~h}$ at ambient temperature. Typical results are summarized in Table III.

Although the present results alone do not allow us to elucidate the mechanism of the formation of 5 by the non-electrochemical procedure, the process described in Chart 2 can be proposed in the light of various studies reported on the reactions between tertiary phosphines and disulfides. ${ }^{16)}$ In the reduction of disulfides with phosphines and water to give thiols and phosphine oxides, protonation of the thiolate anion by an acid ( $c f$. Eq. 6) has been suggested to suppress the dissociation of the initially formed phosphonium ion back to the starting materials ( $c f$. Eq. 5). ${ }^{17)}$

The low yield of $5(\mathrm{R}=\mathrm{Ph})$ can be ascribed to its reaction with $\mathrm{PhCOOLi}$ or $\mathrm{PhCOO}^{-}$, which remains in the medium as described above: $\mathrm{PhCOSPh}$ was formed as a by-product. In the CCE, $\mathbf{5}(\mathrm{R}=\mathrm{Ph})$ was obtained in a fair yield (Table II), probably because the reaction time 


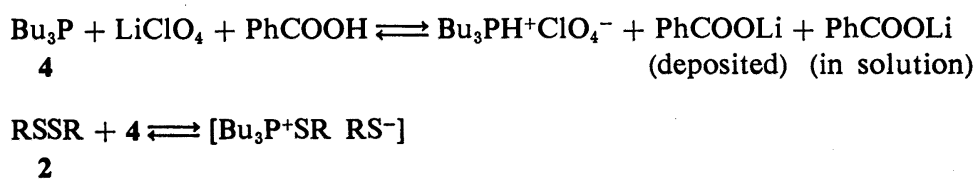

$\left[\mathrm{Bu}_{3} \mathrm{P}^{+} \mathrm{SR} \mathrm{RS}{ }^{-}\right]+\mathrm{Bu}_{3} \mathrm{PH}^{+} \mathrm{ClO}_{4}^{-} \longrightarrow \mathrm{Bu}_{3} \mathrm{P}^{+} \mathrm{SR}^{-} \mathrm{ClO}_{4}^{-}+\mathrm{RSH}+4$

Chart 2

is shorter than in the non-electrochemical procedure. The reason for the failure to obtain $\mathbf{5}$ $(\mathrm{R}=$ sec $-\mathrm{Bu}$ and tert $\mathrm{Bu})$ may be similar to that given for $3(\mathrm{R}=$ tert $-\mathrm{Bu})$, but some contribution of other unknown causes cannot be ruled out.

The non-electrochemical procedure was also applied to the preparation of $\mathbf{3}$, and the results are included in Table III.

\section{Reactions of the Phosphonium Salts 5}

As reported for $5\left(\mathrm{R}=\mathrm{Me} ; \mathrm{X}=\mathrm{OSO}_{2} \mathrm{C}_{6} \mathrm{H}_{4} \mathrm{Me}-p, \mathrm{OSO}_{2} \mathrm{CF}_{3}\right.$, and $\left.\mathrm{BF}_{4}\right),{ }^{4)}$ the reactions of 5 prepared in the present study with carboxylic acids and alcohols were examined. When an equimolar mixture of $\mathbf{5}$, a simple carboxylic acid or a primary alcohol, and a base in benzene

TABLE IV. Reaction of $\mathrm{Bu}_{3} \mathrm{P}^{+} \mathrm{SR} \mathrm{ClO}_{4}{ }^{-}(5)$ with $\mathrm{R}^{\prime} \mathrm{COOH}^{a)}$

\begin{tabular}{|c|c|c|c|c|c|}
\hline $\mathrm{R}$ in 5 & $\mathbf{R}^{\prime}$ & Base & $\begin{array}{c}\text { Yield } \\
(\% /)^{b)} \text { of } \\
\mathrm{R}^{\prime} \mathrm{COSR}\end{array}$ & $\begin{array}{c}\text { bp }\left({ }^{\circ} \mathrm{C}\right) / \text { Torr } \\
\text { [lit.] }\end{array}$ & $\begin{array}{c}{ }^{1} \mathrm{H}-\mathrm{NMR} \delta\left(\mathrm{CDCl}_{3}, J=\mathrm{Hz}\right) \\
{\left[\operatorname{IR} v \mathrm{~cm}^{-1}\right]^{\mathrm{c})}}\end{array}$ \\
\hline \multirow[t]{2}{*}{$\mathrm{Me}$} & \multirow[t]{2}{*}{$\mathrm{Ph}$} & DMAP & 61 & $79 / 2$ & $2.47(3 \mathrm{H}, \mathrm{s}), 7.2-8.1(5 \mathrm{H}, \mathrm{m})[1660$ \\
\hline & & DBU & 98 & {$[124 / 15]^{d)}$} & $1595,1580]^{e)}$ \\
\hline \multirow[t]{2}{*}{$\mathrm{Me}$} & \multirow[t]{2}{*}{$\mathrm{Me}\left(\mathrm{CH}_{2}\right)_{5}$} & DMAP & 72 & $82 / 13$ & $0.7-1.1(3 \mathrm{H}, \mathrm{m}), 1.2-2.0(8 \mathrm{H}, \mathrm{m}), 2.30$ \\
\hline & & DBU & 79 & & $(3 \mathrm{H}, \mathrm{s}), 2.62(2 \mathrm{H}, \mathrm{t}, J=8)[1690]$ \\
\hline \multirow[t]{2}{*}{$\mathrm{Me}$} & \multirow[t]{2}{*}{$\mathrm{Me}\left(\mathrm{CH}_{2}\right)_{4} \mathrm{CH}=\mathrm{CH}$} & DMAP & 39 & $82 / 3$ & $0.8-1.0(3 \mathrm{H}, \mathrm{m}), 1.0-1.7(6 \mathrm{H}, \mathrm{m}), 2.0$ \\
\hline & & DBU & $12^{f)}$ & & $\begin{array}{l}2.4(2 \mathrm{H}, \mathrm{m}), 2.36(3 \mathrm{H}, \mathrm{s}), 6.1-6.2(1 \mathrm{H}, \\
\mathrm{m}), 6.8-7.1(1 \mathrm{H}, \mathrm{m})[1680,1630]\end{array}$ \\
\hline \multirow[t]{2}{*}{ Et } & \multirow[t]{2}{*}{$\mathrm{Ph}$} & DMAP & 60 & $80 / 3$ & $1.32(3 \mathrm{H}, \mathrm{t}, J=8), 3.05(2 \mathrm{H}, \mathrm{q}, J=8)$ \\
\hline & & DBU & 72 & {$[58 / 0.25]^{g)}$} & $7.2-8.1(5 \mathrm{H}, \mathrm{m})[1660,1595,1580]$ \\
\hline \multirow[t]{2}{*}{$\operatorname{Pr}$} & \multirow[t]{2}{*}{$\mathrm{Ph}$} & DMAP & 60 & $123 / 9$ & $1.05(3 \mathrm{H}, \mathrm{t}, J=7), 1.4-2.1(2 \mathrm{H}, \mathrm{m}), 3.05$ \\
\hline & & DBU & 70 & {$[164-170 / 47]^{h)}$} & $\begin{array}{l}(2 \mathrm{H}, \mathrm{t}, J=7), 7.2-8.2(5 \mathrm{H}, \mathrm{m})[1660 \\
1600,1580]\end{array}$ \\
\hline \multirow[t]{2}{*}{$\mathrm{Bu}$} & \multirow[t]{2}{*}{$\mathrm{Ph}$} & DMAP & 74 & $106-109 / 3$ & $0.7-1.1(3 \mathrm{H}, \mathrm{m}), 1.2-2.0(4 \mathrm{H}, \mathrm{m}), 2.9-$ \\
\hline & & DBU & 64 & {$[125 / 5]^{i)}$} & $\begin{array}{l}3.3(2 \mathrm{H}, \mathrm{m}), 7.2-8.2(5 \mathrm{H}, \mathrm{m})[1665 \\
1600,1580]\end{array}$ \\
\hline \multirow[t]{2}{*}{$\mathrm{Bu}$} & \multirow{2}{*}{$\mathrm{Me}\left(\mathrm{CH}_{2}\right)_{5}$} & DMAP & 66 & $101-110 / 25$ & $0.7-1.1(6 \mathrm{H}, \mathrm{m}), 1.1-1.9(12 \mathrm{H}, \mathrm{m}), 2.52$ \\
\hline & & DBU & 83 & & $(2 \mathrm{H}, \mathrm{t}, J=7), 2.85(2 \mathrm{H}, \mathrm{t}, J=7)[1690]$ \\
\hline \multirow[t]{2}{*}{$\mathrm{Ph}$} & \multirow[t]{2}{*}{$\mathrm{Ph}$} & DMAP & 61 & $53-54^{j)}$ & $7.1-8.1(10 \mathrm{H}, \mathrm{m})[1670,1580]^{e)}$ \\
\hline & & $\mathrm{DBU}$ & 85 & {$[55-56]^{k)}$} & \\
\hline \multirow[t]{2}{*}{$\mathrm{Ph}$} & \multirow[t]{2}{*}{$\mathrm{Me}\left(\mathrm{CH}_{2}\right)_{5}$} & DMAP & 90 & $131-137 / 3$ & $0.7-1.1(3 \mathrm{H}, \mathrm{m}), 1.2-1.9(8 \mathrm{H}, \mathrm{m}), 2.62$ \\
\hline & & DBU & 72 & & $\begin{array}{l}(2 \mathrm{H}, \mathrm{t}, J=7), 7.3-7.7(5 \mathrm{H}, \mathrm{m})[1710 \\
1585]\end{array}$ \\
\hline \multirow[t]{2}{*}{$\mathrm{PhCH}_{2}$} & \multirow[t]{2}{*}{$\mathrm{Ph}$} & DMAP & 84 & $34.5-35.5^{j)}$ & $4.29(2 \mathrm{H}, \mathrm{s}), 7.1-8.1(10 \mathrm{H}, \mathrm{m})[1660$ \\
\hline & & DBU & 62 & {$[36-38]^{l)}$} & $1600,1580,1500]$ \\
\hline
\end{tabular}

a) The salt 5, $\mathrm{R}^{\prime} \mathrm{COOH}$, and the base $(5 \mathrm{mmol}$ apiece) in benzene $(5 \mathrm{ml})$ were stirred for $12 \mathrm{~h}$ at ambient temperature. $b$ ) Isolated yield. $c$ ) The IR spectra were obtained with the neat liquid unless otherwise stated. $d$ ) R. Mayer, S. Scheithauer, and D. Kunz, Chem. Ber., 99, $1393(1966)$. e) Obtained in Nujol. $f$ ) Mixture of $\mathrm{Me}\left(\mathrm{CH}_{2}\right)_{4} \mathrm{CH}=\mathrm{CHCOSMe}$ and $\mathrm{Me}\left(\mathrm{CH}_{2}\right)_{4} \mathrm{CH}(\mathrm{SMe}) \mathrm{CH}_{2} \mathrm{COSMe}$ g) G. A. Olah, M. R. Bruce, and F. L. Clouet, J. Org. Chem., 49, $438(1981)$. h) W. R. Vaugham and J. B. Baumann, J. Org. Chem., 27, 739 (1962). i) S. Yamada, Y. Yokoyama, and T. Shioiri, J. Org. Chem., 39, 3302 (1974). j) mp $\left({ }^{\circ} \mathrm{C}\right)$. k) T. Inamoto, M. Kodera, and M. Yokoyama, Synthesis, 1982, $134 . \quad l$ ) W. Hieber and D. von Pigenot, Chem. Ber., 89, 193 (1956). 
TABLE V. Reaction of $\mathrm{Bu}_{3} \mathrm{P}^{+} \mathrm{SR} \mathrm{X} \mathrm{X}^{-}(5)$ with $\mathrm{R}^{\prime \prime} \mathrm{OH}^{a)}$

\begin{tabular}{|c|c|c|c|c|c|}
\hline $\mathrm{R}$ & $\mathrm{X}$ & $\mathbf{R}^{\prime \prime}$ & $\begin{array}{l}\text { Yield }(\%)^{b)} \\
\text { of RSR" }\end{array}$ & $\begin{array}{c}\text { bp }\left({ }^{\circ} \mathrm{C}\right) / \text { Torr } \\
\text { [lit.] }\end{array}$ & ${ }^{1} \mathrm{H}-\mathrm{NMR} \delta\left(\mathrm{CDCl}_{3}, J=\mathrm{Hz}\right)$ \\
\hline $\mathrm{Me}$ & $\begin{array}{l}\mathrm{ClO}_{4} \\
\mathrm{BF}_{4}\end{array}$ & $\mathrm{PhCH}_{2}$ & $\begin{array}{l}72^{c)}(92)^{c, d)} \\
92^{c)}\end{array}$ & $\begin{array}{l}95-98 / 25 \\
{[94-96 / 18]^{e)}}\end{array}$ & $\begin{array}{l}2.00(3 \mathrm{H}, \mathrm{s}), 3.69(2 \mathrm{H}, \mathrm{s}), 7.1-7.4(5 \mathrm{H}, \\
\mathrm{m})\end{array}$ \\
\hline $\mathrm{Me}$ & $\begin{array}{l}\mathrm{ClO}_{4} \\
\mathrm{BF}_{4}\end{array}$ & $\mathrm{Me}\left(\mathrm{CH}_{2}\right)_{7}$ & $\begin{array}{l}55 \\
35\end{array}$ & $\begin{array}{l}75 / 35 \\
{[97 / 16]^{f)}}\end{array}$ & $\begin{array}{l}0.5-1.1(3 \mathrm{H}, \mathrm{m}), 1.0-1.8(12 \mathrm{H}, \mathrm{m}) \\
2.07(3 \mathrm{H}, \mathrm{s}), 2.50(2 \mathrm{H}, \mathrm{t}, J=7)\end{array}$ \\
\hline $\mathrm{Me}$ & $\begin{array}{l}\mathrm{ClO}_{4} \\
\mathrm{BF}_{4}\end{array}$ & $\mathrm{Me}\left(\mathrm{CH}_{2}\right)_{2} \mathrm{CH}=\mathrm{CHCH}_{2}$ & $\begin{array}{l}32 \\
33\end{array}$ & $63-64 / 25$ & $\begin{array}{l}0.7-1.1(3 \mathrm{H}, \mathrm{m}), 1.1-1.2(4 \mathrm{H}, \mathrm{m}) \\
2.00(3 \mathrm{H}, \mathrm{s}), 3.04(2 \mathrm{H}, \mathrm{d}, J=6), 5.1- \\
5.8(2 \mathrm{H}, \mathrm{m})\end{array}$ \\
\hline $\mathrm{Me}$ & $\begin{array}{l}\mathrm{ClO}_{4} \\
\mathrm{BF}_{4}\end{array}$ & $\mathrm{Me}\left(\mathrm{CH}_{2}\right)_{5} \mathrm{CHMe}$ & $\begin{array}{r}10 \\
7\end{array}$ & $\begin{array}{c}94-98 / 15 \\
{[84-85.5 / 10]^{g)}}\end{array}$ & $\begin{array}{l}0.8-1.1(3 \mathrm{H}, \mathrm{m}), 1.2-1.8(13 \mathrm{H}, \mathrm{m}) \\
2.05(3 \mathrm{H}, \mathrm{s}), 2.4-3.0(1 \mathrm{H}, \mathrm{m})\end{array}$ \\
\hline $\mathrm{Me}$ & $\mathrm{ClO}_{4}$ & $\mathrm{MeCH}_{2} \mathrm{CMe}_{2}$ & 0 & & \\
\hline Et & $\mathrm{ClO}_{4}$ & $\mathrm{PhCH}_{2}$ & 54 & $\begin{array}{c}98 / 13 \\
{[68 / 4]^{h)}}\end{array}$ & $\begin{array}{l}1.19(3 \mathrm{H}, \mathrm{t}, J=7), 2.40(2 \mathrm{H}, \mathrm{q}, J=7) \\
3.68(2 \mathrm{H}, \mathrm{s}), 7.1-7.4(5 \mathrm{H}, \mathrm{m})\end{array}$ \\
\hline $\operatorname{Pr}$ & $\mathrm{ClO}_{4}$ & $\mathrm{PhCH}_{2}$ & 68 & $\begin{array}{l}99-103 / 10 \\
{[83-84 / 6]^{i)}}\end{array}$ & $\begin{array}{l}0.91(3 \mathrm{H}, \mathrm{t}, J=7), 1.2-1.9(2 \mathrm{H}, \mathrm{m}), \\
2.36(2 \mathrm{H}, \mathrm{t}, J=7), 3.64(2 \mathrm{H}, \mathrm{s}), 7.1- \\
7.4(5 \mathrm{H}, \mathrm{m})\end{array}$ \\
\hline $\mathrm{Bu}$ & $\mathrm{ClO}_{4}$ & $\mathrm{PhCH}_{2}$ & 55 & $\begin{array}{c}101-104 / 14 \\
{[102-104 / 2]^{i)}}\end{array}$ & $\begin{array}{l}0.7-1.0(3 \mathrm{H}, \mathrm{m}), 1.1-1.8(4 \mathrm{H}, \mathrm{m}) \\
2.38(2 \mathrm{H}, \mathrm{t}, J=7), 3.65(2 \mathrm{H}, \mathrm{s}), 7.1- \\
7.4(5 \mathrm{H}, \mathrm{m})\end{array}$ \\
\hline $\mathrm{Ph}$ & $\mathrm{ClO}_{4}$ & $\mathrm{Me}\left(\mathrm{CH}_{2}\right)_{2} \mathrm{CH}=\mathrm{CHCH}_{2}$ & $69(85)^{d)}$ & $102-106 / 2$ & $\begin{array}{l}0.6-1.0(3 \mathrm{H}, \mathrm{m}), 1.0-2.2(4 \mathrm{H}, \mathrm{m}), \\
3.4-3.6(2 \mathrm{H}, \mathrm{m}), 5.3-5.6(2 \mathrm{H}, \mathrm{m}), \\
7.0-7.6(5 \mathrm{H}, \mathrm{m})\end{array}$ \\
\hline $\mathrm{PhCH}_{2}$ & $\mathrm{ClO}_{4}$ & $\mathrm{PhCH}_{2}$ & 48 & $\begin{array}{l}47-48^{j)} \\
{[47-49]^{j, k)}}\end{array}$ & $3.39(4 \mathrm{H}, \mathrm{s}), 7.2-7.5(10 \mathrm{H}, \mathrm{m})$ \\
\hline
\end{tabular}

a) The phosphonium salt $5, \mathrm{R}^{\prime \prime} \mathrm{OH}$, and $\mathrm{DBU}(10 \mathrm{mmol}$ each) in benzene $(10 \mathrm{ml})$ were stirred for $48 \mathrm{~h}$ at ambient temperature. b) Isolated yield. c) Determined by gas chromatography [PEG-20M (10\%) as packing]. d) In $\mathrm{CH}_{2} \mathrm{Cl}_{2} . \quad$ e) $\mathrm{T}$. Ichikawa, H. Owatari, and T. Kato, J. Org. Chem., 35, $344(1970)$. f) I. Degani, R. Fochi, and V. Regondi, Synthesis, 1983, 630. g) H. Matsuyama, H. Minato, and M. Kobayashi, Bull. Chem. Soc. Jpn., 48, 3287 (1975). h) M. Furukawa, T. Suda, and S. Hayashi, Synthesis, 1974, 282. i) T. Kubota, S. Miyashita, T. Kitazume, and N. Ishikawa, J. Org. Chem., 45, 5052 (1980). j) mp $\left({ }^{\circ}\right.$ C). k) R. S. Davidson, J. Chem. Soc. $(C), 1967,2131$.

was stirred at ambient temperature, the corresponding thiolester or unsymmetrical sulfide, respectively, was obtained in fair to excellent yield. As the base, 4-(dimethylamino)pyridine (DMAP) and/or 1,8-diazabicyclo[5.4.0]undec-7-ene (DBU) were found to afford favorable results. Reactions of 5 with unsaturated acids or with secondary and tertiary alcohols gave poor yields of the expected products. Typical results are collected in Tables IV and V.

As described so far, the phosphonium salts $\mathbf{3}$ and $\mathbf{5}$ can be prepared from disulfides $\mathbf{2}$ and the phosphines 1 and 4, respectively, either by the CCE method or by the non-electrochemical reaction, both in one step without the use of any special or unstable reagents: the yields of the phosphonium salts are comparable to or a little lower than those (usually $>70 \%$ ) reported in the alkylation of phosphine sulfides. ${ }^{4,5}$ For the preparation of 3 , which is a useful reagent for the synthesis of unsymmetrical disulfides, ${ }^{1)}$ the CCE method is recommended, because it requires no extra reagent other than $\mathrm{HClO}_{4}$ and the yield of 3 was always better than that attained by the non-electrochemical reaction: in the work-up, remaining $\mathrm{HClO}_{4}$ can be removed easily (see Experimental). On the other hand, the non-electrochemical procedure is obviously superior to its electrochemical counterpart for the preparation of $\mathbf{5}$ with primary thioalkoxy groups.

Several methods have been developed to obtain thiolesters ${ }^{18)}$ and unsymmetrical sulfides ${ }^{19)}$ starting from carboxylic acids or their activated forms and from alcohols or alkyl halides, respectively. As mentioned by Haynes and Indorato ${ }^{4}{ }^{4}$ however, the present methods 
with the phosphonium salts 5 at least by-pass the inconvenience of using thiols or their metal salts. The phosphonium salts $\mathbf{5}$ as well as $\mathbf{3}$ are stable and can be stored over a long period simply in a stoppered bottle.

\section{Experimental}

All melting points are uncorrected. Infrared (IR) and nuclear magnetic resonance $\left({ }^{1} \mathrm{H}-\mathrm{NMR}\right)$ spectra were measured with Nippon Bunko A202 and Hitachi R-20 spectrometers, respectively. Cyclic voltammetry was carried out essentially as described previously. ${ }^{20)}$ CCE was performed using a conventional DC power supply (50 V-2 A).

Materials - The phosphine 1 was recrystallized from hexane, and $\mathbf{4}$ was distilled under reduced pressure. $\mathrm{LiClO}_{4}$ was recrystallized from $95 \%$ ethanol and stored over $\mathrm{P}_{2} \mathrm{O}_{5}$ under reduced pressure. Commercially available

TABLE VI. Physical and ${ }^{1} \mathrm{H}-\mathrm{NMR}$ Spectral Data for $\mathrm{Ph}_{3} \mathrm{P}^{+} \mathrm{SR} \mathrm{ClO}_{4}{ }^{-}(3)$ and $\mathrm{Bu}_{3} \mathrm{P}^{+} \mathrm{SR} \mathrm{X}^{-}(5)^{a)}$

\begin{tabular}{|c|c|c|c|c|}
\hline \multirow{2}{*}{ Compd. } & \multirow{2}{*}{$\begin{array}{l}\text { Formula and } \\
\qquad \mathrm{mp}\left({ }^{\circ} \mathrm{C}\right)\end{array}$} & \multicolumn{2}{|c|}{$\begin{array}{l}\text { Analysis }(\%) \\
\text { Calcd (Found) }\end{array}$} & \multirow{2}{*}{${ }^{1} \mathrm{H}-\mathrm{NMR} \delta\left(\mathrm{CDCl}_{3}, J=\mathrm{Hz}\right)$} \\
\hline & & $\mathrm{C}$ & $\mathrm{H}$ & \\
\hline $3(\mathrm{R}=\mathrm{Me})$ & $\begin{array}{c}\mathrm{C}_{19} \mathrm{H}_{18} \mathrm{ClO}_{4} \mathrm{PS} \\
139-140\end{array}$ & $\begin{array}{r}55.82 \\
(55.54\end{array}$ & $\begin{array}{l}4.44 \\
4.35)\end{array}$ & $2.47\left(3 \mathrm{H}, \mathrm{d}, J_{\mathrm{PH}}=15\right), 7.4-8.0(15 \mathrm{H}, \mathrm{m})$ \\
\hline $3(\mathrm{R}=\mathrm{Et})$ & $\begin{array}{c}\mathrm{C}_{20} \mathrm{H}_{20} \mathrm{ClO}_{4} \mathrm{PS} \\
191-192\end{array}$ & $\begin{array}{r}56.81 \\
(56.63\end{array}$ & $\begin{array}{l}4.77 \\
4.64)\end{array}$ & $\begin{array}{l}1.35\left(3 \mathrm{H}, \mathrm{t}, J_{\mathrm{HH}}=7.5\right), 2.98\left(2 \mathrm{H}, \mathrm{dq}, J_{\mathrm{HH}}=7.5, J_{\mathrm{PH}}=11\right), \\
7.4-8.0(15 \mathrm{H}, \mathrm{m})\end{array}$ \\
\hline $3(\mathrm{R}=\mathrm{Pr})$ & $\begin{array}{c}\mathrm{C}_{21} \mathrm{H}_{22} \mathrm{ClO}_{4} \mathrm{PS} \\
169-170\end{array}$ & $\begin{array}{r}57.73 \\
(57.67\end{array}$ & $\begin{array}{l}5.08 \\
5.09)\end{array}$ & $\begin{array}{l}0.94\left(3 \mathrm{H}, \mathrm{t}, J_{\mathrm{HH}}=7\right), 1.68\left(2 \mathrm{H}, \mathrm{tq}, J_{\mathrm{HH}}=7,7\right), 2.98(2 \mathrm{H}, \mathrm{dt} \\
\left.J_{\mathrm{HH}}=7, J_{\mathrm{PH}}=11\right), 7.5-8.1(15 \mathrm{H}, \mathrm{m})\end{array}$ \\
\hline $3(\mathrm{R}=\mathrm{Bu})$ & $\begin{array}{c}\mathrm{C}_{22} \mathrm{H}_{24} \mathrm{ClO}_{4} \mathrm{PS} \\
140-141\end{array}$ & $\begin{array}{r}58.60 \\
(58.47\end{array}$ & $\begin{array}{l}5.36 \\
5.31)\end{array}$ & $\begin{array}{l}0.80\left(3 \mathrm{H}, \mathrm{t}, J_{\mathrm{HH}}=7\right), 1.0-2.0(4 \mathrm{H}, \mathrm{m}), 2.93\left(2 \mathrm{H}, \mathrm{dt}, J_{\mathrm{HH}}=7,\right. \\
\left.J_{\mathrm{PH}}=11\right), 7.4-8.1(15 \mathrm{H}, \mathrm{m})\end{array}$ \\
\hline $3(\mathrm{R}=\sec -\mathrm{Bu})$ & $\begin{array}{l}\mathrm{C}_{22} \mathrm{H}_{24} \mathrm{ClO}_{4} \mathrm{PS} \\
103-104\end{array}$ & $\begin{array}{r}58.60 \\
(58.51\end{array}$ & $\begin{array}{l}5.36 \\
5.32)\end{array}$ & $\begin{array}{l}0.91\left(3 \mathrm{H}, \mathrm{t}, J_{\mathrm{HH}}=7\right), 1.31\left(3 \mathrm{H}, \mathrm{d}, J_{\mathrm{HH}}=7\right), 1.62(2 \mathrm{H}, \mathrm{dq} \\
\left.J_{\mathrm{HH}}=7,7\right), 2.87-3.67(1 \mathrm{H}, \mathrm{m}), 7.5-8.1(15 \mathrm{H}, \mathrm{m})\end{array}$ \\
\hline $3(\mathrm{R}=\mathrm{Ph})$ & $\begin{array}{c}\mathrm{C}_{24} \mathrm{H}_{20} \mathrm{ClO}_{4} \mathrm{PS} \\
172-173\end{array}$ & $\begin{array}{r}61.21 \\
(61.41\end{array}$ & $\begin{array}{l}4.28 \\
4.26)\end{array}$ & $7.8-8.0(20 \mathrm{H}, \mathrm{m})$ \\
\hline $3\left(\mathrm{R}=\mathrm{PhCH}_{2}\right)$ & $\begin{array}{l}\mathrm{C}_{25} \mathrm{H}_{22} \mathrm{ClO}_{4} \mathrm{PS} \\
141-142\end{array}$ & $\begin{array}{r}61.92 \\
(61.81\end{array}$ & $\begin{array}{l}4.57 \\
4.40)\end{array}$ & $4.12\left(2 \mathrm{H}, \mathrm{d}, J_{\mathrm{PH}}=11\right), 7.0-7.3(5 \mathrm{H}, \mathrm{m}), 7.4-8.1(15 \mathrm{H}, \mathrm{m})$ \\
\hline $\begin{aligned} 5(\mathrm{R} & =\mathrm{Me} \\
\mathrm{X} & \left.=\mathrm{ClO}_{4}\right)\end{aligned}$ & $\begin{array}{c}\mathrm{C}_{13} \mathrm{H}_{30} \mathrm{ClO}_{4} \mathrm{PS} \\
60-61\end{array}$ & $\begin{array}{r}44.76 \\
(44.61\end{array}$ & $\begin{array}{l}8.67 \\
8.95)\end{array}$ & $\begin{array}{l}0.7-1.2(9 \mathrm{H}, \mathrm{m}), 1.3-1.8(12 \mathrm{H}, \mathrm{m}), 2.3-2.9(6 \mathrm{H}, \mathrm{m}), 2.50 \\
\left(3 \mathrm{H}, \mathrm{d}, J_{\mathrm{PH}}=13\right)\end{array}$ \\
\hline $\begin{aligned} 5(\mathrm{R} & =\mathrm{Me} \\
\mathrm{X} & \left.=\mathrm{BF}_{4}\right)\end{aligned}$ & $\begin{array}{c}\mathrm{C}_{13} \mathrm{H}_{30} \mathrm{BF}_{4} \mathrm{PS} \\
52-53\end{array}$ & $\begin{array}{r}46.44 \\
(46.26\end{array}$ & $\begin{array}{l}8.99 \\
9.21)\end{array}$ & $\begin{array}{l}0.8-1.2(9 \mathrm{H}, \mathrm{m}), 1.3-1.9(12 \mathrm{H}, \mathrm{m}), 2.2-2.8(6 \mathrm{H}, \mathrm{m}), 2.48 \\
\left(3 \mathrm{H}, \mathrm{d}, J_{\mathrm{PH}}=13\right)\end{array}$ \\
\hline $\begin{aligned} 5(\mathrm{R} & =\mathrm{Et} \\
\mathrm{X} & \left.=\mathrm{ClO}_{4}\right)\end{aligned}$ & $\begin{array}{c}\mathrm{C}_{14} \mathrm{H}_{32} \mathrm{ClO}_{4} \mathrm{PS} \\
75-76\end{array}$ & $\begin{array}{r}46.34 \\
(46.24\end{array}$ & $\begin{array}{l}8.89 \\
9.11)\end{array}$ & $\begin{array}{l}0.7-1.2(9 \mathrm{H}, \mathrm{m}), 1.3-1.8(15 \mathrm{H}, \mathrm{m}), 2.3-2.9(6 \mathrm{H}, \mathrm{m}), 3.10 \\
\left(2 \mathrm{H}, \mathrm{dq}, J_{\mathrm{HH}}=7, J_{\mathrm{PH}}=10\right)\end{array}$ \\
\hline $\begin{aligned} 5(\mathrm{R} & =\mathrm{Et} \\
\mathrm{X} & \left.=\mathrm{BF}_{4}\right)\end{aligned}$ & $\begin{array}{c}\mathrm{C}_{14} \mathrm{H}_{32} \mathrm{BF}_{4} \mathrm{PS} \\
42-43\end{array}$ & $\begin{array}{r}48.01 \\
(47.96\end{array}$ & $\begin{array}{l}9.21 \\
9.56)\end{array}$ & $\begin{array}{l}0.8-1.2(9 \mathrm{H}, \mathrm{m}), 1.3-1.9(15 \mathrm{H}, \mathrm{m}), 2.1-2.8(6 \mathrm{H}, \mathrm{m}), 3.03 \\
\left(2 \mathrm{H}, \mathrm{dq}, J_{\mathrm{HH}}=8, J_{\mathrm{PH}}=10\right)\end{array}$ \\
\hline $\begin{aligned} 5(\mathrm{R} & =\mathrm{Pr} \\
\mathrm{X} & \left.=\mathrm{ClO}_{4}\right)\end{aligned}$ & $\begin{array}{c}\mathrm{C}_{15} \mathrm{H}_{34} \mathrm{ClO}_{4} \mathrm{PS} \\
61-62\end{array}$ & $\begin{array}{r}47.80 \\
(47.56\end{array}$ & $\begin{array}{l}9.09 \\
9.26)\end{array}$ & $\begin{array}{l}0.7-1.2(12 \mathrm{H}, \mathrm{m}), 1.3-2.1(14 \mathrm{H}, \mathrm{m}), 2.3-2.9(6 \mathrm{H}, \mathrm{m}) \\
3.03\left(2 \mathrm{H}, \mathrm{dt}, J_{\mathrm{HH}}=7, J_{\mathrm{PH}}=9\right)\end{array}$ \\
\hline $\begin{aligned} 5(\mathrm{R} & =\mathrm{Pr} \\
\mathrm{X} & \left.=\mathrm{BF}_{4}\right)\end{aligned}$ & $\begin{array}{c}\mathrm{C}_{15} \mathrm{H}_{34} \mathrm{BF}_{4} \mathrm{PS} \\
62-63\end{array}$ & $\begin{array}{r}49.46 \\
(49.60\end{array}$ & $\begin{array}{l}9.41 \\
9.66)\end{array}$ & $\begin{array}{l}0.8-1.3(12 \mathrm{H}, \mathrm{m}), 1.3-2.1(14 \mathrm{H}, \mathrm{m}), 2.1-2.7(6 \mathrm{H}, \mathrm{m}) \\
3.04\left(2 \mathrm{H}, \mathrm{dt}, J_{\mathrm{HH}}=8, J_{\mathrm{PH}}=10\right)\end{array}$ \\
\hline $\begin{aligned} 5(\mathrm{R} & =\mathrm{Bu} \\
\mathrm{X} & \left.=\mathrm{ClO}_{4}\right)\end{aligned}$ & $\begin{array}{c}\mathrm{C}_{16} \mathrm{H}_{36} \mathrm{ClO}_{4} \mathrm{PS} \\
56-57\end{array}$ & $\begin{array}{r}49.16 \\
(48.92\end{array}$ & $\begin{array}{l}9.28 \\
9.50)\end{array}$ & $\begin{array}{l}0.7-1.2(12 \mathrm{H}, \mathrm{m}), 1.3-2.0(16 \mathrm{H}, \mathrm{m}), 2.3-2.8(6 \mathrm{H}, \mathrm{m}) \\
3.05\left(2 \mathrm{H}, \mathrm{dt}, J_{\mathrm{HH}}=7, J_{\mathrm{PH}}=10\right)\end{array}$ \\
\hline $\begin{aligned} 5(\mathrm{R} & =\mathrm{Bu} \\
\mathrm{X} & \left.=\mathrm{BF}_{4}\right)\end{aligned}$ & $\begin{array}{c}\mathrm{C}_{16} \mathrm{H}_{36} \mathrm{BF}_{4} \mathrm{PS} \\
57-58\end{array}$ & $\begin{array}{r}50.80 \\
(50.82\end{array}$ & $\begin{array}{l}9.59 \\
9.88)\end{array}$ & $\begin{array}{l}0.8-1.2(12 \mathrm{H}, \mathrm{m}), 1.2-1.9(16 \mathrm{H}, \mathrm{m}), 2.2-2.8(6 \mathrm{H}, \mathrm{m}) \\
3.05\left(2 \mathrm{H}, \mathrm{dt}, J_{\mathrm{HH}}=8, J_{\mathrm{PH}}=9\right)\end{array}$ \\
\hline $\begin{aligned} 5(\mathrm{R} & =\mathrm{Ph} \\
\mathrm{X} & \left.=\mathrm{ClO}_{4}\right)\end{aligned}$ & $\begin{array}{c}\mathrm{C}_{18} \mathrm{H}_{32} \mathrm{ClO}_{4} \mathrm{PS} \\
56-57\end{array}$ & $\begin{array}{r}52.61 \\
(52.38\end{array}$ & $\begin{array}{l}7.85 \\
8.02)\end{array}$ & $\begin{array}{l}0.7-1.2(9 \mathrm{H}, \mathrm{m}), 1.2-2.0(12 \mathrm{H}, \mathrm{m}), 2.2-2.7(6 \mathrm{H}, \mathrm{m}) \\
7.3-7.8(5 \mathrm{H}, \mathrm{m})\end{array}$ \\
\hline $\begin{aligned} 5(\mathrm{R} & =\mathrm{PhCH}_{2} \\
\mathrm{X} & \left.=\mathrm{ClO}_{4}\right)\end{aligned}$ & $\begin{array}{c}\mathrm{C}_{19} \mathrm{H}_{34} \mathrm{ClO}_{4} \mathrm{PS} \\
88-89\end{array}$ & $\begin{array}{r}53.70 \\
(53.54\end{array}$ & $\begin{array}{l}8.06 \\
8.21)\end{array}$ & $\begin{array}{l}0.7-1.2(9 \mathrm{H}, \mathrm{m}), 1.3-2.0(12 \mathrm{H}, \mathrm{m}), 2.3-2.8(6 \mathrm{H}, \mathrm{m}), 4.25 \\
\left(2 \mathrm{H}, \mathrm{d}, J_{\mathrm{PH}}=11\right), 7.1-7.6(5 \mathrm{H}, \mathrm{m})\end{array}$ \\
\hline $\begin{aligned} 5(\mathrm{R} & =\mathrm{PhCH}_{2} \\
\mathrm{X} & \left.=\mathrm{BF}_{4}\right)\end{aligned}$ & $\begin{array}{c}\mathrm{C}_{19} \mathrm{H}_{34} \mathrm{BF}_{4} \mathrm{PS} \\
86-87\end{array}$ & $\begin{array}{r}55.35 \\
(55.49\end{array}$ & $\begin{array}{l}8.31 \\
8.61)\end{array}$ & $\begin{array}{l}0.8-1.2(9 \mathrm{H}, \mathrm{m}), 1.3-1.9(12 \mathrm{H}, \mathrm{m}), 2.2-2.8(6 \mathrm{H}, \mathrm{m}), 4.20 \\
\left(2 \mathrm{H}, \mathrm{d}, J_{\mathrm{PH}}=10\right), 7.1-7.5(5 \mathrm{H}, \mathrm{m})\end{array}$ \\
\hline
\end{tabular}

a) IR spectra of the phosphonium salts with $\mathrm{ClO}_{4}{ }^{-}$showed characteristic absorption at around $1100 \mathrm{~cm}^{-1}$, and those with $\mathrm{BF}_{4}{ }^{-}$ at around $1050 \mathrm{~cm}^{-1}$. 
anhydrous $\mathrm{LiBF}_{4}$ was used without further purification. $\mathrm{MeCN}$ was purified by the method of Kiesele. ${ }^{211}$ Other chemicals were obtained from commercial sources and were purified, if necessary, by distillation or recrystallization.

General Procedure for the Electrochemical Preparation of $3-$ A $50 \mathrm{ml}$ sample tube (diameter, $3.5 \mathrm{~cm}$; height, $7.5 \mathrm{~cm})$ was used as the electrolysis cell, which was equipped with a graphite plate anode $(1 \times 10 \mathrm{~cm})$ and a platinum foil cathode $(1 \times 10 \mathrm{~cm})^{22)}$ through a silicon stopper. A solution of $1(2 \mathrm{mmol}), 2(4 \mathrm{mmol})$, and $70 \% \mathrm{HClO}_{4}(4 \mathrm{mmol}$ as $\left.\mathrm{HClO}_{4}\right)$ in $\mathrm{MeCN}(40 \mathrm{ml})$ was placed in the cell: caution, $\mathrm{HClO}_{4}$ should be added slowly to the mixture of 1 and 2 in $\mathrm{MeCN}$ with stirring. The system was subjected to CCE $\left(50 \mathrm{~mA}\right.$; current density, $\left.c a .6 \mathrm{~mA} / \mathrm{cm}^{2}\right)$ at ambient temperature until $1 \mathrm{~F}$ per mol of $1(193 \mathrm{C}, \mathrm{ca} .65 \mathrm{~min})$ had been consumed. The electrolyzed solution was concentrated to $c a .2 \mathrm{ml}$ under reduced pressure at below $30^{\circ} \mathrm{C}$. Ether $(100 \mathrm{ml})$ was added to the residue. The phosphonium salt 3 that separated out (as colorless crystals) was filtered off, washed with ether and AcOEt, and recrystallized from MeCOEt and AcOEt. The physical and spectroscopic data for $\mathbf{3}$ are summarized in Table VI. CCE with a larger amount of 1 was carried out in a $200 \mathrm{ml}$ beaker (diameter, $5.5 \mathrm{~cm}$; height, $10 \mathrm{~cm}$ ): a graphite plate of $3 \times 10 \mathrm{~cm}$ was used as the anode. A mixture of $1(50 \mathrm{mmol}), 2(100 \mathrm{mmol})$, and $70 \% \mathrm{HClO}_{4}(100 \mathrm{mmol})$ in $\mathrm{MeCN}(150 \mathrm{ml})$ was subjected to CCE $\left(70 \mathrm{~mA}\right.$; current density, $\left.c a .2 \mathrm{~mA} / \mathrm{cm}^{2}\right)$ as described above $(c a .20 \mathrm{~h})$ : at the beginning of electrolysis, it is not necessary to dissolve 1 completely in the medium.

General Procedure for the Electrochemical Preparation of 5-A mixture of 4 (7.5 mmol), $2(15 \mathrm{mmol})$, $\mathrm{PhCOOH}(7.5 \mathrm{mmol}), \mathrm{LiClO}_{4}(30 \mathrm{mmol})$ and $\mathrm{Al}_{2} \mathrm{O}_{3}(0.2 \mathrm{~g})$ in $\mathrm{MeCN}(40 \mathrm{ml})$ was subjected to CCE in a $50 \mathrm{ml} \mathrm{sample}$ tube (see above) under the conditions cited in Table II until $1 \mathrm{~F}$ per mol of 4 had been consumed. The electrolyzed solution, after deposited $\mathrm{PhCOOLi}$ and $\mathrm{Al}_{2} \mathrm{O}_{3}$ had been removed by filtration, was concentrated to $\mathrm{ca}$. $2 \mathrm{ml}$ under reduced pressure. Water $(40 \mathrm{ml})$ was added to the residue and the mixture was extracted with $\mathrm{CHCl}_{3}(5 \times 20 \mathrm{ml})$. The extracts were dried over anhydrous $\mathrm{MgSO}_{4}$ and concentrated to $c a$. $2 \mathrm{ml}$. When ether (200 ml) was added to the residue, the phosphonium salt $\mathbf{5}$ separated out as colorless crystals, which were filtered off, washed with ether, and recrystallized from AcOEt and ether. The physical and spectroscopic data for $\mathbf{5}$ are given in Table VI.

General Procedure for the Non-electrochemical Preparation of 5-A mixture of 4 (12.5 mmol), 2 (12.5 mmol), $\mathrm{PhCOOH}(12.5 \mathrm{mmol}), \mathrm{LiClO}_{4}$ or $\mathrm{LiBF}_{4}(12.5 \mathrm{mmol})$, and $\mathrm{Al}_{2} \mathrm{O}_{3}(0.2 \mathrm{~g})$ in $\mathrm{MeCN}(20 \mathrm{ml})$ was stirred at ambient temperature for $12 \mathrm{~h}$. Work-up of the reaction mixture as described above gave the phosphonium salt 5 . The preparation of $\mathbf{3}$ was performed by essentially the same procedure.

Reaction of 5 with Carboxylic Acids-- Essentially the same procedure as reported by Haynes and Indorato ${ }^{4)}$ was employed. Thus, the phosphonium salt $5(5 \mathrm{mmol})$ was added in one portion to a solution of a carboxylic acid $(5 \mathrm{mmol})$ and a base (DBU or DMAP) $(5 \mathrm{mmol})$ in benzene $(5 \mathrm{ml}),{ }^{23)}$ and the resulting mixture was stirred at ambient temperature for $24 \mathrm{~h}$. Insoluble material in the reaction mixture was filtered off, and the filtrate was evaporated under reduced pressure. The residue was then subjected to column chromatography on silica gel [hexane-AcOEt (20:1)] to give the expected thiolester, which was purified by vacuum distillation.

Reaction of 5 with Alcohols - Compound $5(10 \mathrm{mmol})$ was added in one portion to a solution of an alcohol $(10 \mathrm{mmol})$ and DBU $(10 \mathrm{mmol})$ in benzene or $\mathrm{CH}_{2} \mathrm{Cl}_{2}(10 \mathrm{ml})$. The mixture was stirred at ambient temperature for $48 \mathrm{~h}$, and then filtered. The filtrate was evaporated under reduced pressure, and the residue was subjected to column chromatography on silica gel [hexane-AcOEt $(40: 1)$ ] to give the expected unsymmetrical sulfide.

Acknowledgement This work was supported in part by a Grant-in-Aid for Scientific Research (60570987) from the Ministry of Education, Science and Culture.

\section{References and Notes}

1) M. Masui, Y. Mizuki, K. Sakai, C. Ueda, and H. Ohmori, J. Chem. Soc., Chem. Commun., $1984,843$.

2) T..Endo, S. Ikenaga, and T. Mukaiyama, Bull. Chem. Soc. Jpn., 43, 2632 (1970).

3) H. Ohmori, H. Maeda, K. Sakai, and M. Masui, unpublished results.

4) R. K. Haynes and C. Indorato, Aust. J. Chem., 37, 1183 (1984).

5) A. Hantsch and H. Hibbert, Ber., 40, 1508 (1907); L. Horner and H. Winker, Tetrahedron Lett., 1964, $175 ;$ C. Glidewell and E. J. Leslie, J. Chem. Soc., Dalton Trans., 1977, 527; J. Omelanczuk and M. Mikołajczyk, J. Am. Chem. Soc., 101, 7292 (1979), and Tetrahedron Lett., 1984, 2493; D. H. R. Barton, D. P. Manly, and D. A. Widdowson, J. Chem. Soc., Perkin Trans. 1, 1975, 1568; L. Horner and M. Jordan, Phosphorus and Sulfur, 8, 209 and $215(1980)$.

6) H. Ohmori, S. Nakai, M. Sekiguchi, and M. Masui, Chem. Pharm. Bull., 28, 910 (1980).

7) Preparation of $\mathbf{3}$ by CCE has been briefly mentioned (ref. 1).

8) Since $70 \% \mathrm{HClO}_{4}$ obtained from a commercial source was used without any treatment, the reaction medium inevitably contained a small amount of water.

9) Cathodic reduction of $\mathbf{3}$ in $\mathrm{MeCN}$ was found to give $\mathbf{1}$ and 2.

10) Higher yields of 5 were observed when water was deliberately added to the medium along with $\mathrm{NaClO}_{4}$. However, it was rather difficult to find the optimum amount of water required in each experiment.

11) S. Torii, "Electroorganic Synthesis (Part 1: Oxidations)," Kodansha, Tokyo, and VCH, Weinheim, 1985, pp. 
$57-58,61-62,85-86,125,223-224$, and $310-313$.

12) In the CPE method, the amount of electricity required for the formation of 3 has been found to be $1 \mathrm{~F}$ per mol of 1.

13) The voltammetric peak of 1 in the presence of $\mathrm{HClO}_{4}$ may be ascribed to the oxidation of $\mathrm{Ph}_{3} \mathrm{PH}^{+}$to $\mathrm{Ph}_{3} \mathrm{P}^{+}$ and $\mathrm{H}^{+}$, though further studies are required to elucidate the exact nature of the electrode process.

14) The yield of 5 was improved a little on CCE at $0^{\circ} \mathrm{C}$.

15) C. A. Steuli, Anal. Chem., 32, 985 (1960).

16) T. Mukaiyama and H. Takei, "Topics in Phosphorus Chemistry," Vol. 8, ed. by E. J. Griffith and M. Grayson, John Wiley and Sons, Inc., New York, 1976, pp. 587-645.

17) Ref. 16, pp. 620-621.

18) E. Haslam, Tetrahedron, 36, 2409 (1980); H.-J. Liu and S. I. Sabesan, Can. J. Chem., 58, 2645 (1980); S. Kim and S. Yang, Chem. Lett., 1981, 133; Y. Kawanami, Y. Dainobu, J. Inanaga, T. Katsuki, and M. Yamaguchi, Bull. Chem. Soc. Jpn.,.54, 943 (1981); T. Inamoto, M. Kodera, and M. Yokoyama, Synthesis, 1982, 134; K. Soai, H. Hayàshi, and A. Ookawa, J. Chem. Res., 1983, 20; and references cited therein.

19) N. Ono, H. Miyake, T. Sato, and A. Kaji, Synthesis, 1980, 952; J. T. B. Ferreira, J. V. Comasseto, and A. J. Braga, Synth. Commun., 12, 595 (1982); W. Ando, T. Furuhata, H. Tsumaki, and A. Sekiguchi, ibid., 12, 627 (1982); M. Yamato, Y. Takeuchi, K. Hattori, and K. Hashigaki, Synthesis, 1982, 1014; I. Degani, R. Fochi, and V. Regondi, ibid., 1983, 630; J. C. Sih and D. R. Graber, J. Org. Chem., 48, 3842 (1983); F. A. Luzzio, Synth. Commun., 14, 209 (1984); and references cited therein.

20) H. Ohmori, A. Matsumoto, and M. Masui, J. Chem. Soc., Perkin Trans. 2, 1980, 347.

21) H. Kiesele, Anal. Chem., 52, 2230 (1980).

22) A stainless steel plate or a graphite plate can also be used as the cathode.

23) The mixture was warmed, if necessary, to obtain a clear solution. 